ANDRIJA VIDOVIĆ, Ph.D.

University of Zagreb,

Faculty of Transport and Traffic Sciences

Vukelićeva 4, 10000 Zagreb, Croatia

IGOR ŠTIMAC, M.Sc.

E-mail: istimac@zagreb-airport.hr

Zagreb Airport Ltd.

Pleso bb, 10000 Zagreb, Croatia

\title{
DEVELOPMENT POTENTIALS OF LOW COST AVIATION IN THE REPUBLIC OF CROATIA
}

\begin{abstract}
The liberalization of the aviation market has enabled low-cost airlines to take over a significant share in the aviation market. Benefits of low-cost models are multiple, both for passengers and for secondary and regional airports, which were neglected in the past and which record significant inflow of passengers with the arrival of low-cost airlines.

In the structure of the air traffic in the Republic of Croatia in the last ten years, there has been a progressive growth of foreign low-cost airline operations, which suggests a potential for the operation of a Croatian low-cost airline.

This paper defines the criteria applicable to modelling of a low-cost airline in the Republic of Croatia in the relevant context of fleet management, route networking and operator's processes in traffic technology. It analyzes the dynamics of low-cost airlines operations in the structure of air traffic in Croatia and the impact of traffic on the status of airports and the national operator.
\end{abstract}

\section{KEY WORDS}

low-cost airline, traditional airline, airport, route network, fleet management

\section{INTRODUCTION}

Deregulation of aviation markets has created a new segment of the so-called low-cost airlines (LCA) which base their model on optimization of the capacity of the same model of aircraft used by traditional operators and have high frequency and high utilization of aircraft, a specific reservation system, standardized fleet and a specific en-route concept.

The concept was developed in the 1970s in the United States, after which it was applied in the early nineties in Europe and in the rest of the world. Market liberalization in 1997 enabled low-cost airlines to gradually increase their share in the traffic volumes and the share of traditional companies was gradually reduced.

Functional organization and the associated traffic and technological processes applied in low-cost airlines resulted in up to 50 percent lower operating costs compared to traditional companies. Currently in Europe there are 58 low-cost airlines that operate and they generate 38 percent of total passenger traffic and 23 percent of total Instrumental Flight Rules (IFR) operations.

Recently, in the structure of air traffic in Croatia a significant increase has been noticed in the share of low-cost airlines. Aircraft operations in domestic traffic have been reduced to the national operator and a small number of charter companies, while completely lacking proper development of the fleet of general and business aviation to respond to latent demand in domestic and regional traffic.

Although traffic at Croatian airports is increasing every year, airport capacity is still under-utilized. Passenger traffic at Croatian airports in the pre-war years amounted to around 5.5 million passengers carried, while the current number of passengers carried is around 5 million. Except for Zagreb, Split and Dubrovnik Airports, other Croatian airports have significant development potential in terms of acquisition of additional, particularly unconventional operations.

\section{ORGANIZATIONAL MODEL OF LOW-COST AIRLINES}

Deregulation of the U.S. aviation market started back in 1978, which means much earlier than in the rest of the world. One of the products of deregulation of the aviation market was the appearance of low-cost airlines. The best known company that operates under this principle is Southwest Airlines after which many others 
appeared and most failed to "survive" the competition in the last three decades. The percentage of companies is surprisingly high considering the extremely high profits that these companies were making.

The appearance of low-cost airlines resulted in further liberalization and integration of aviation markets in Europe. It also led to a significant inflow of travellers in an otherwise neglected, secondary and regional airports, forcing other airports to be more efficient and competitive. Low-cost airlines provide air travel at reasonable prices, they provide more jobs and economic growth, they simplified travel within Europe, forced the traditional airlines and airports to reduce cost and be more efficient, reduced the congestion at major European airports and increased competitiveness. Regions in which low-cost airlines direct their flights have recognized the role of these companies as important social and economic initiators of regional development. The arrival of these companies has resulted in job creation; the rather neglected regions have been put on the map of destinations and have the option of free advertising on internet sites of the airlines and more likely inflow of tourists throughout the year [1].

Low-cost airlines base their business model on continuous monitoring of the market and they close the non-profit lines in a very short time and then follow rerouting of the existing fleet to new, profitable destinations. Low-cost airlines have two initial advantages over the traditional operators, namely: higher capacity of aircraft obtained by reducing the space between the seats and the possibility of higher daily utilization of aircraft as result of shorter handling time. Since there are no classes of passengers onboard aircraft and be- cause of reduced legroom, low-cost airlines have more seats in their planes. Low-cost airlines have a space between the seats of $71-74 \mathrm{~cm}$ while traditional operators have $79-81 \mathrm{~cm}$. EasyJet's Boeing 737-300 places up to 149 passengers in the same model of aircraft as the British Midland company which has 132 seats. In the case of a large number of business passengers, they move seats, and 124 passengers can be placed in the aircraft. Even if these two companies have similar operating costs, the fact remains that, at best, an easyJet aircraft can accommodate 25 passengers more, resulting in 16-17 percent lower cost per seatkilometre [2].

In order to offer lower prices and thereby remain profitable, low-cost airlines must have significantly lower unit costs than the traditional operators. Table 1 shows an overview of the costs of low-cost airlines on short-haul flights (less than 3 hours). The initial index of the cost per seat on the route of traditional companies is 100 .

Table 2 shows the traffic growth at the airports that use low-cost airlines. In comparison, the traffic at the airports in the UK for the same period increased by 37 percent.

Low-cost airlines use secondary and uncongested airports since by bringing a significant number of passengers to these airports they have usually signed agreements on favourable airport charges. Low cost airlines, therefore, do not build their own "low-cost airports" and do not invest heavily in their development. They use the opportunity that there is a large number of underserved airports that can hardly survive without bringing fresh capital. Low-cost airlines offer to

Table 1 - Cost distribution of low-cost airlines on short-haul flights in relation to traditional operators [3]

\begin{tabular}{||l|c|c||}
\hline & Cost reduction (\%) & Cost per seat \\
\hline \hline Traditional scheduled airline & & \\
\hline \hline Low-cost airline & & \\
\hline Operating advantages: & & 84 \\
\hline Higher seating density & -16 & 82 \\
\hline Higher aircraft utilisation & -2 & 79 \\
\hline Lower flight and cabin crew costs & -3 & 75 \\
\hline Use of cheaper secondary airports & -4 & 73 \\
\hline Outsourcing maintenance/single aircraft type & -2 & 66 \\
\hline Product/service features: & & 61 \\
\hline Minimal station costs and outsourced handling & -7 & \\
\hline No free in-flight catering, fewer passenger services & -5 & 55 \\
\hline Differences in distribution: & & 52 \\
\hline No agents or GDS commissions & -6 & \\
\hline Reduced sales/reservation costs & -3 & \\
\hline Other advantages: & & \\
\hline Smaller administration and fewer staff/offices & -3 & \\
\hline \hline Low-cost compared to traditional airline & & \\
\hline \hline
\end{tabular}


A. Vidović, S. Steiner, I. Štimac: Development Potentials of Low Cost Aviation in the Republic of Croatia

Table 2 - Traffic growth of secondary airports due to the influence of low-cost airlines [4]

\begin{tabular}{||l|c|c|c||}
\hline \multicolumn{1}{|c|}{ Airport } & Scheduled passengers 1995 & Scheduled passengers 2002 & Growth \\
\hline \hline Stansted & $2,900,000$ & $17,800,000$ & $405 \%$ \\
\hline Luton & 600,000 & $5,400,000$ & $873 \%$ \\
\hline Liverpool & 400,000 & $2,400,000$ & $551 \%$ \\
\hline Prestwick & 200,000 & $1,300,000$ & $508 \%$ \\
\hline Other GB airports & $92,600,000$ & $126,600,000$ & $37 \%$ \\
\hline \hline
\end{tabular}

local authorities, where there are such airports, agreements of mutual benefit in which the airline provides new jobs and promotes business and tourism opportunities in the region, and in return the local government provides better conditions for the use of the airport. In most cases, these contracts are an asset to both parties concerned.

\section{STATUS AND DEVELOPMENT POTENTIAL OF LOW-COST AIRLINES IN THE REPUBLIC OF CROATIA}

There were three registered airlines which owned a large aircraft fleet in Croatia in 2009. The largest airline and the only one registered for the scheduled traffic is Croatia Airlines. Following by capacity are Dubrovnik Airline and Trade Air. These two companies are orientated to charter flights or aircraft rental.

The airlines in Croatia have low capacity and they can hardly compete with much stronger companies in the EU market, where competition is substantially more pronounced and where a large number of lowcost airlines operate, whose fleet consists of over a hundred aircraft. With a small number of aircraft it is difficult to develop a network of destinations and to maintain the number of frequencies that will meet the market needs. Croatia Airlines became a member of Star Alliance Regional, giving it on one hand, better treatment among competitors, but on the other hand, making it lose a part of its sovereignty and independence in conducting the business policy and the establishment of new destinations [5].

Dubrovnik Airline and Trade Air have not signed up for the scheduled transport, and the cooperation between these companies is minor. In addition, companies that do not perform scheduled transport cannot use the state aid in air traffic to perform services of general economic interest. The concept of services of general economic interest in the European Union includes those economic services that are of particular importance for the citizens of a country that cannot be provided without government intervention, or would be provided under different or unfavourable conditions than the existing ones.

Although they have existed in Europe for more than a decade, the phenomenon of low-cost airlines came to Croatia with several years of delay. The reason lies mainly in market size and in the fact that the total annual number of passengers carried in Croatia is the tenth of the traffic of some eminent European airports (e.g. Frankfurt) and underrepresented marketing that would explain to potential users that flying is no longer a luxury, which can be proved by fares of low-cost airlines.

The first low-cost airline in scheduled traffic in Croatia was Germanwings. They established in 2004 a year-round service between Cologne (Bonn) and Zagreb and seasonal service between Cologne (Bonn) and Split, and soon after the introduction of the line from Cologne to Zagreb and Split they introduced lines from Berlin, Stuttgart, Hamburg and Bonn for Croatia. These were the first Croatian cities that are connected daily with the German cities.

After Germanwings entered the market, other lowcost airlines became interested in the establishment of flights. Forerunners for low-cost airlines, especially during the tourist season, were the charter companies. Charter and low-cost airlines generate additional volume of traffic and additional revenue, but the airport must continue with its strategy to stimulate new network carriers.

Figure 1 shows that the structure of competition completely changed with the entrance of low-cost airlines on the aviation market in Croatia. The market share of low-cost airlines increased in only four years from 4 percent to 36 percent, while the share of Croatia Airlines is showing a large drop (from $64 \%$ to $40 \%$ ).

In scheduled air traffic in 2008 there were 36 foreign carriers (of which 15 traditional airlines, and 21 low-cost airlines), which is 20 percent more than in 2007, from 48 destinations (+23\%), with 337 flights in the peak weeks of operation. In charter traffic 35 foreign carriers $(+75 \%)$ were flying from 36 European destinations (+71\%) with 46 flights in the peak weeks of operation.

There are seven registered international airports in Croatia: Zagreb, Dubrovnik, Split, Zadar, Pula, Rijeka, Osijek and two smaller airports open for public traffic (Mali Lošinj and Brač) in domestic and international traffic. Croatia has eighteen registered airports for general aviation and occasional business aviation traffic, three airfields and three heliports (used by companies and hospitals). 


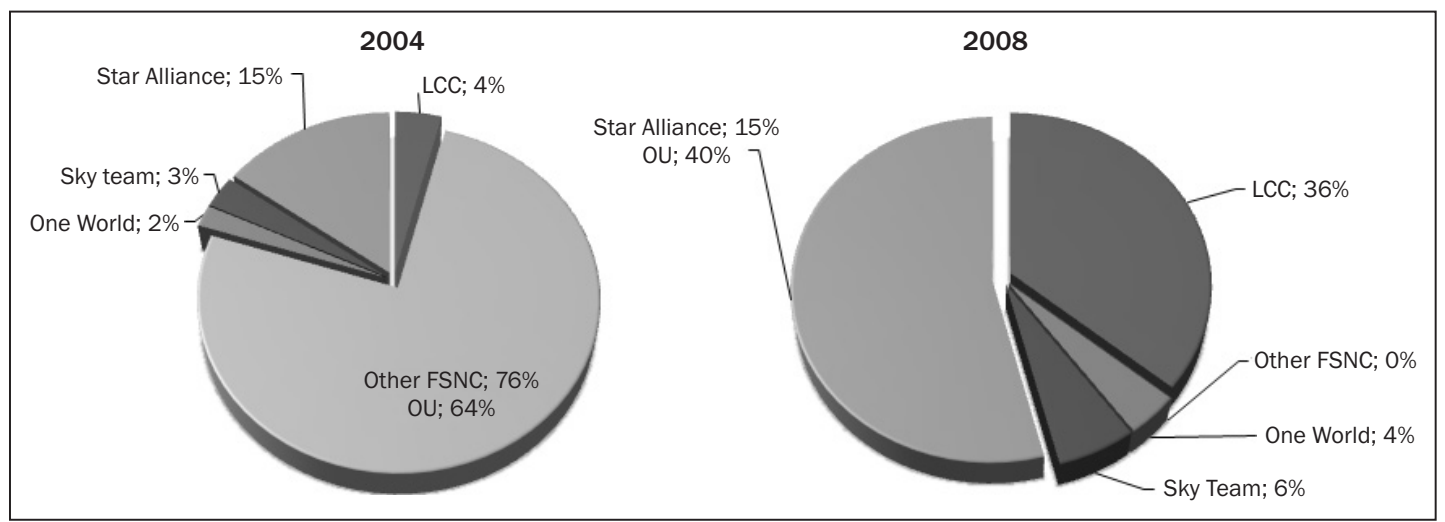

Figure 1 - Market share of airlines in Croatia [6]

Only three airports in Croatia, in commercial sense, achieve satisfactory results and potential profitability. The State, as the majority owner of the Croatian airports, confirms the thesis of poor management, but also unacceptable indifference in the issues of future development, although setting aside substantial budgetary resources for their subsidies. On the other hand, plans for building new airports are successively elaborated and implemented without a unified vision and a more systematic consideration of possible options of the corporatization of the existing unprofitable airport, and without a comprehensive development strategy of the Croatian airports.

Table 3 shows the share of low-cost airlines at Croatian airports in 2009. The share of low-cost airlines in traffic at the Zagreb Airport is extremely low compared to other Croatian airports. Transportation is performed by two low-cost airlines, Germanwings and Wizz Air. The biggest traffic of LCA was recorded in 2008 when they transported more than 245,000 passengers. This was followed by a decline in passengers in 2009 due to the cancellation of destinations. Norwegian and easyJet announced their arrival in 2010 and this share should increase significantly. The increase in traffic that new operators will bring is another argument for the necessity of building a new terminal at the Zagreb Airport.

At the Split Airport the number of low-cost airlines increased from nine companies in 2004 to sixteen companies in 2008 , and the proportion of total passenger traffic increased from 9 to 35 percent.

Three low-cost airlines began with flights to Dubrovnik in 2004 and the proportion of total passengers amounted to little more than 3 percent. In 2008 there were nine low-cost airlines at the airport and that made 25 percent of total passenger traffic, while data for 2009 in the number of companies and share in passengers are similar as in 2008. In the future an increased inflow of low-cost airlines is expected that will increase in the coming years its stake by over 30 percent of the total passenger traffic at the Dubrovnik Airport.

By the end of 2009 the Pula Airport had business contracts with low-cost airlines Ryanair, Germanwings and Norwegian Air Shuttle. The arrival of the low-cost airlines at the Pula Airport is most responsible for the sudden increase in traffic in 2006 that has continued in the coming years. The share of low-cost airlines at the Pula Airport is 24 percent, but it should be noted that business and general aviation are not included in the traffic. If these parameters were also included in the analysis, one could arrive to the data that this percentage was actually 18.4 , i.e. the number of passengers carried by low-cost airlines is 58,835 .

Low-cost airlines had a great impact on the traffic performance of the Rijeka Airport. The arrival of the carrier Hapag-Lloyd Express to Rijeka was conditioned by a much lower cost per passenger because the market was not promising high load factors. Practice has shown that the Primorje-Gorski Kotar County generated significant traffic demand, so in 2005 it achieved 115 percent higher annual number of passengers compared to 2004 , or 122,000 passengers more. Thus, the Rijeka Airport became the first airport in Croatia, which after Croatia had gained independence exceeded the pre-war traffic. For the moment, the Rijeka Airport, one of the smaller airports in Croatia, manages to attract the largest share of low-cost airlines in total traffic, primarily by offering lower price of airport

Table 3 - Traffic effects of LCA on the Croatian airports

\begin{tabular}{||l|c|c|c|c|c|c|c||}
\hline \multicolumn{1}{|c|}{ Airport } & Zagreb & Split & Dubrovnik & Pula & Rijeka & Zadar & Osijek \\
\hline \hline Total pax. 2009 & $2,056,388$ & $1,080,121$ & $1,109,934$ & 302,448 & 110,208 & 195,163 & 20,503 \\
\hline No. LCA & 2 & 16 & 9 & 3 & 4 & 3 & 1 \\
\hline Share LCA & $9.96 \%$ & $35 \%$ & $25 \%$ & $24 \%$ & $81.20 \%$ & $69.20 \%$ & $63.86 \%$ \\
\hline
\end{tabular}

Source: Data submitted by the airports 
services. The traffic growth in 2005 and in 2006 and the share of low-cost airlines in the total traffic of more than 80 percent are the indicators that the strategy of the Rijeka Airport was correct. The Rijeka Airport is the only one in Croatia which announced investments in the infrastructure that is directly connected to the movement of low-cost airlines.

In the period from 2006 to 2009 , at the Zadar Airport the following low-cost airlines were flying: SkyEurope in 2006; Ryanair and Germanwings in 2007; SkyEurope, Germanwings and Ryanair in 2008; SkyEurope, Germanwings and Ryanair in 2009. The share of low-cost airlines in the total traffic has risen from 5.9 percent in 2006 to 69.2 percent in 2009.

For the Osijek Airport it can be concluded that the arrival of LCA brought multiple increase in traffic, but it is important to emphasize that it still is a highly under-capacitated airport. Specifically, in the pre-war times, the Osijek Airport accounted for only 0.7 percent of total passenger traffic (data for 1987 when the Osijek Airport transported 38,917 passengers). But, even though this information was devastating in 1987 , it was significantly better than the traffic data for the entire post-war period. In the period from 2002 to 2007 the number of passengers at the Osijek Airport was between 2,343 and 3,374 and that is not even a tenth of the pre-war traffic. The arrival of low-cost airline Germanwings (in the meantime withdrawn from operations) and Ryanair announced a better future for the airport. Although passenger traffic is still not at a satisfactory level and is still significantly lagging behind the traffic data of other airports, the potential of this airport can be noticeable primarily as a hub for the cargo traffic throughout the region.

\section{MODEL OF LOW-COST AIRLINE IN THE REPUBLIC OF CROATIA}

For the operation of any airline, including low-cost airlines, it is necessary to make a detailed analysis of the market potential. The domestic market in Croatia is limited because it has a population of less than 4.5 million residents, so there are no prerequisites for the application of low-cost airlines only for domestic traffic. Among other things, low-cost traffic which would be based only on the domestic market could not be justified economically considering the incentives that the Croatia Airlines receives from the State for performing a public service obligation. In case there was a cessation of subsidies on the domestic flights of the Croatia Airlines carrier, or in case of the willingness of local communities to finance the costs, low-cost airlines would have a much better chance of achieving positive business impact.

The analysis of traffic impacts of the Croatian airports revealed that in Croatia there is an economic jus- tification for the operation of the 3-4 airports. Due to good transport links and highway distances between each airport (the overlapping of catchment zones), it is not possible to include all Croatian airports in the network of destinations, which is a further restriction for the development of low-cost operations which would be based only on domestic flights.

It is therefore necessary for the market to expand to the region and to destinations that could provide optimum load factors. The obstacle to spreading only to the countries of former Yugoslavia is an unsigned agreement on air transport between Serbia and Croatia, which would be the best outbound market, especially during the tourist season when a large number of Serbian tourists spend their holidays on the Adriatic. Among other markets in the immediate region that have the potential are the markets of Austria, Italy, the Czech Republic, Macedonia, Albania and Montenegro. For each of these markets, because the distance from Zagreb is less than $600 \mathrm{~km}$, it would be optimal to use a turboprop aircraft because they have lower operating costs than jet aircraft.

As the main market for Croatia are the countries of Western Europe, the destinations need to expand to the markets of Germany, France, Great Britain, Spain, Belgium, Switzerland and the one market in the East - Turkey. To link all of these markets, it is necessary to take into consideration jet aircraft of larger capacity and range.

For the election of the airports that will be included in each of the proposed countries the key criteria was that the destination is of the market interest, that they are, if possible, secondary airports and that they, based on the index indicator on the movement of passenger traffic in 2009, started to record a recovery trend caused by global financial crisis and are close to, or are themselves, the main traffic junctions that allow further transfer of passengers.

The result of the previous analysis is the choice of optimal destinations in each of the considered countries. For better coverage of Croatia by air traffic, the following airports have been specified for destinations: Zagreb (which also represented the Hub), Dubrovnik, Split, Zadar and Pula. All the proposed destinations are shown in Figure 2.

For destinations in the immediate region the following airports have been selected: Tirana (Albania), Skopje (Macedonia), Prague (the Czech Republic), Podgorica (Montenegro), Bratislava (Slovakia - substitute for the primary airport Vienna in Austria), Roma Ciampino (Italy - primary airport Roma Fiumicino) and Bergamo - Orio al Serio (Italy - primary airport Milan Malpensa).

For the destinations in more distant countries the following airports have been selected: Zurich (Switzerland), Madrid Barajas (Spain), Brussels South Charleroi (Belgium - primary airport Brussels Airport), 


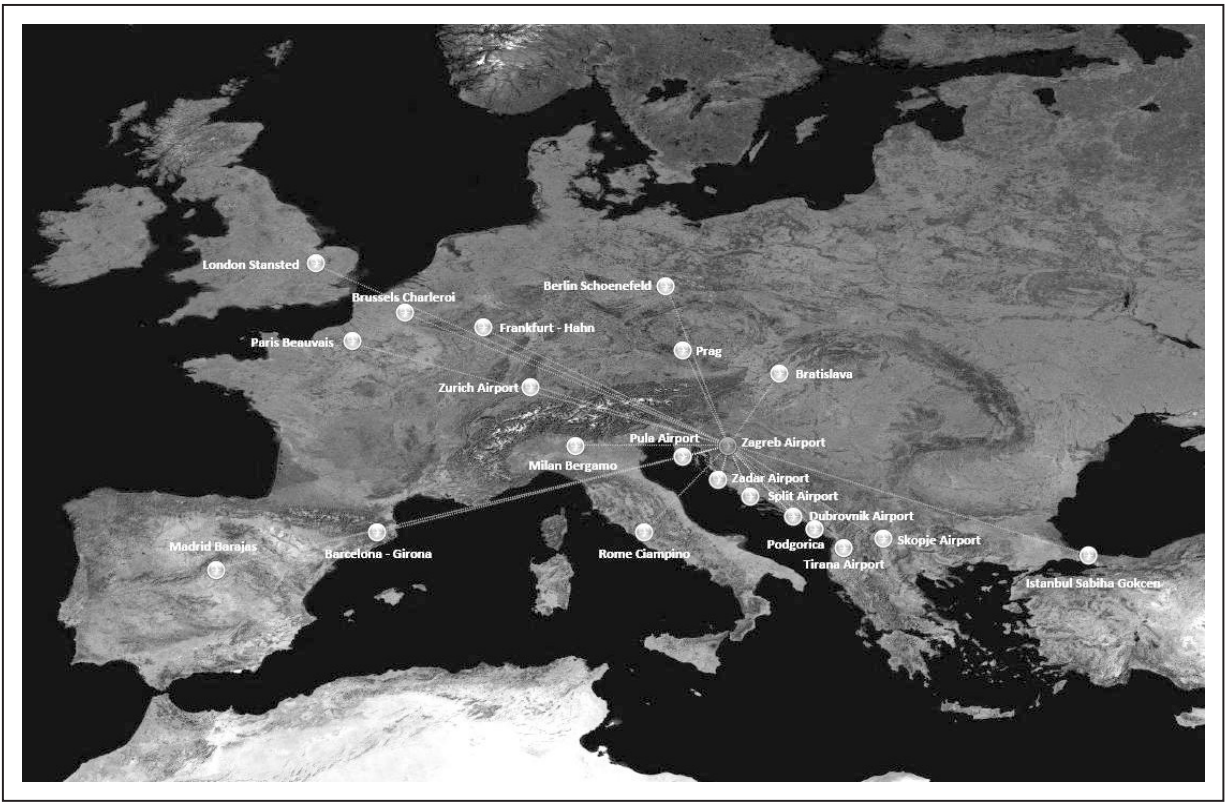

Figure 2 - Map of destinations [7]

Paris-Beauvais-Tille (France - primary airport ParisCharles de Gaulle), Frankfurt Hahn (Germany - primary airport Frankfurt International Airport), BerlinSchoenefeld (Germany - primary airport Berlin-Tegel), London Stansted (United Kingdom - primary airport London Heathrow), Girona-Costa Brava (Spain - primary airport Barcelona El Prat de Llobregat ) and Istanbul Sabiha Gokcen (Turkey - primary airport Istanbul Ataturk).

After having determined the destination airports, it is possible to select the fleet. The most important criterion for the selection of aircraft is determined by the optimal number of seats. To determine the optimal number of seats, it is necessary to compare the movement of passengers from Croatia to suggested destinations, i.e. to analyze the current state of aviation market and make a forecast of future growth. The analysis of the aviation market showed that for the purposes of domestic and regional traffic aircraft should not have more than 80 seats, while for satisfying the need for long-distance international flights optimal aircraft ought to have 120 seats. The following criterion for choosing the optimal aircraft is the payload. It is desirable that the payload of an aircraft is as large as possible and inversely proportional to the third criterion of maximum take-off mass (MTOM). The maximum value of payload is important because the passengers who travel by low-cost airlines are usually tourists who carry large amounts of luggage and for this reason it is important to take note on how to choose an airplane that has a larger capacity of cargo compartments. Maximum take-off mass should be as small as possible in order to reduce the operating costs associated with airport fees that airlines pay just on the basis of this parameter. The next criterion that was analyzed in choosing the optimal aircraft is aircraft performance and required infrastructure needs for take off/landing. It is essential that the optimal aircraft has sufficient speed, operating altitude, range and endurance to connect all of the proposed destinations and to allow greater utilization of aircraft. The parameter of infrastructure needs is important and should be as small as possible because the airplane should land/take off from a larger number of airports.

Although one of the main features of a low-cost model is the use of single type of fleet, in the world renowned low-cost airlines exist that differ from this model and use aircraft from different manufacturers and combined fleet of jet and turboprop aircraft. This is done because for a part of the market the jet aircraft are too big and cannot provide a satisfactory load factor to operate profitably, while piston aircraft are limited regarding range and capacity for longer distances. Low-cost airlines in Europe mainly use B737-800 aircraft with 187 seats or Airbus aircraft A319 and A320, even on routes where there is sufficient demand. One model of aircraft in the fleet is specific characteristic of the largest low-cost airlines. On the aviation market, however, few low-cost airlines operate that combine a fleet of jet and turboprop aircraft. Due to the specific needs of local and regional environment in Croatia, there is a reasoned application of the combined fleet of aircraft consisting of turboprop and jet aircraft. The fleet of low-cost airline operators does not consist of aircraft with capacity less than 50 seats. The aircraft of smaller capacity are applied in the segments of business and general aviation.

With the aim of connecting Croatia in the domestic and regional traffic, it is necessary to choose an aircraft of up to 80 seats. Considering the distances 


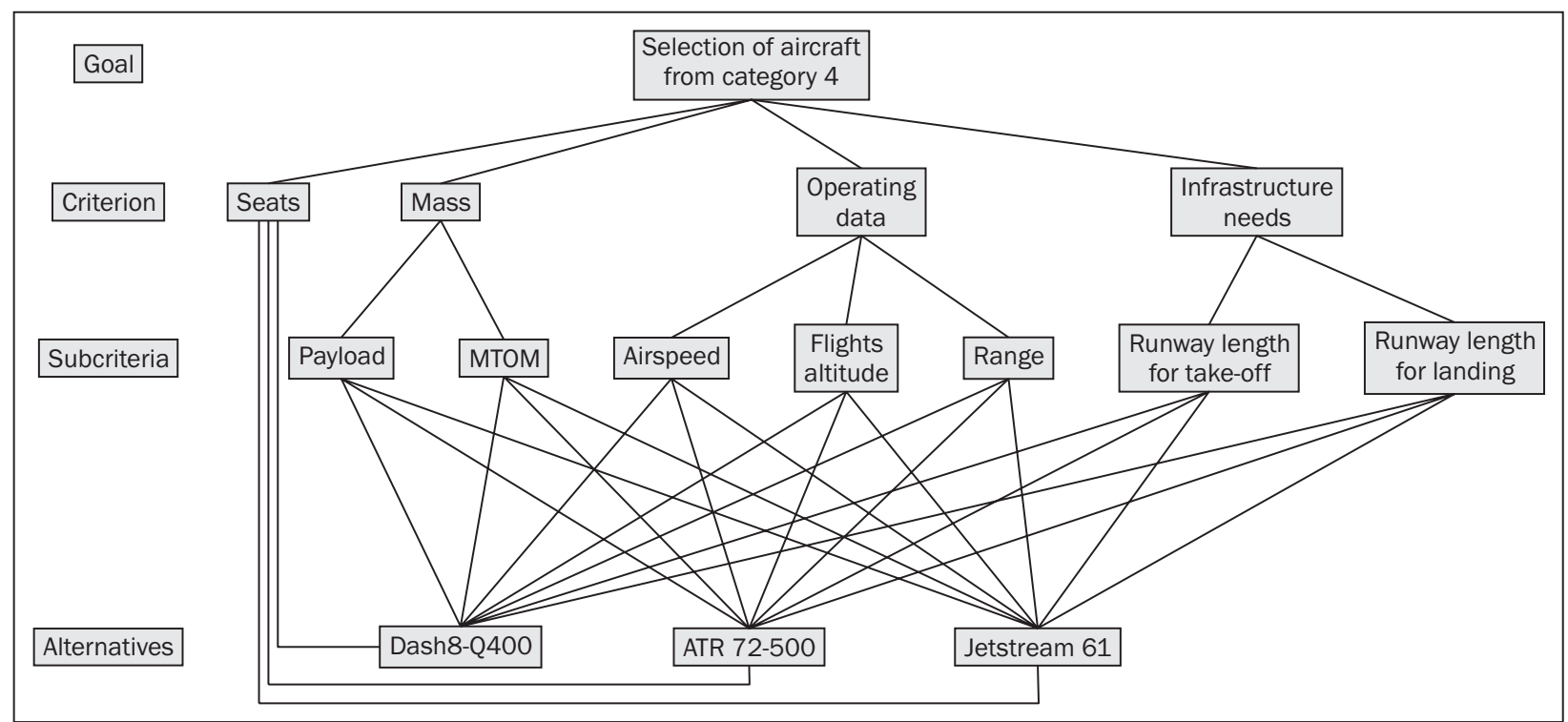

Figure 3 - Scheme of the hierarchical structure of multi-criteria analysis model in the function of selecting the optimal aircraft from Category 4 [7]

between each destination, the logical choice is a turboprop aircraft because at these distances it has significantly lower operating costs. Aircraft with turboprop engines have the disadvantage that the passengers (especially business passengers - in the last few years business passengers have been a growing segment in the share of LCA passengers) prefer planes with jet engines.

Aircraft are divided into seven categories according to the criteria of the number of seats, weight (mass), operational data and infrastructure needs. The first four categories of aircraft are with piston engines and further three categories are aircraft with jet engines. The reason for such a wide range of aircraft was that by using the multi-criteria analysis, according to predetermined criteria, it determines which of the categories are optimal for low-cost airline operations in the domestic and regional traffic. Multi-criteria analysis (Figure 3) proved that the optimal aircraft for regional connectivity is Dash8-Q400, which is one of the types of aircraft in the fleet of the flag carrier Croatia Airlines. The aircraft has a maximum capacity of 78 seats and a break-even point is 56 percent ( 44 seats) at an average rate of 65 euro, while the remaining 34 seats are potential profit. Dash8-Q400 has a cruise speed competitive to block-time of aircraft with jet engine to 740 kilometres, and aircraft operating costs are among the lowest compared to other regional aircraft.

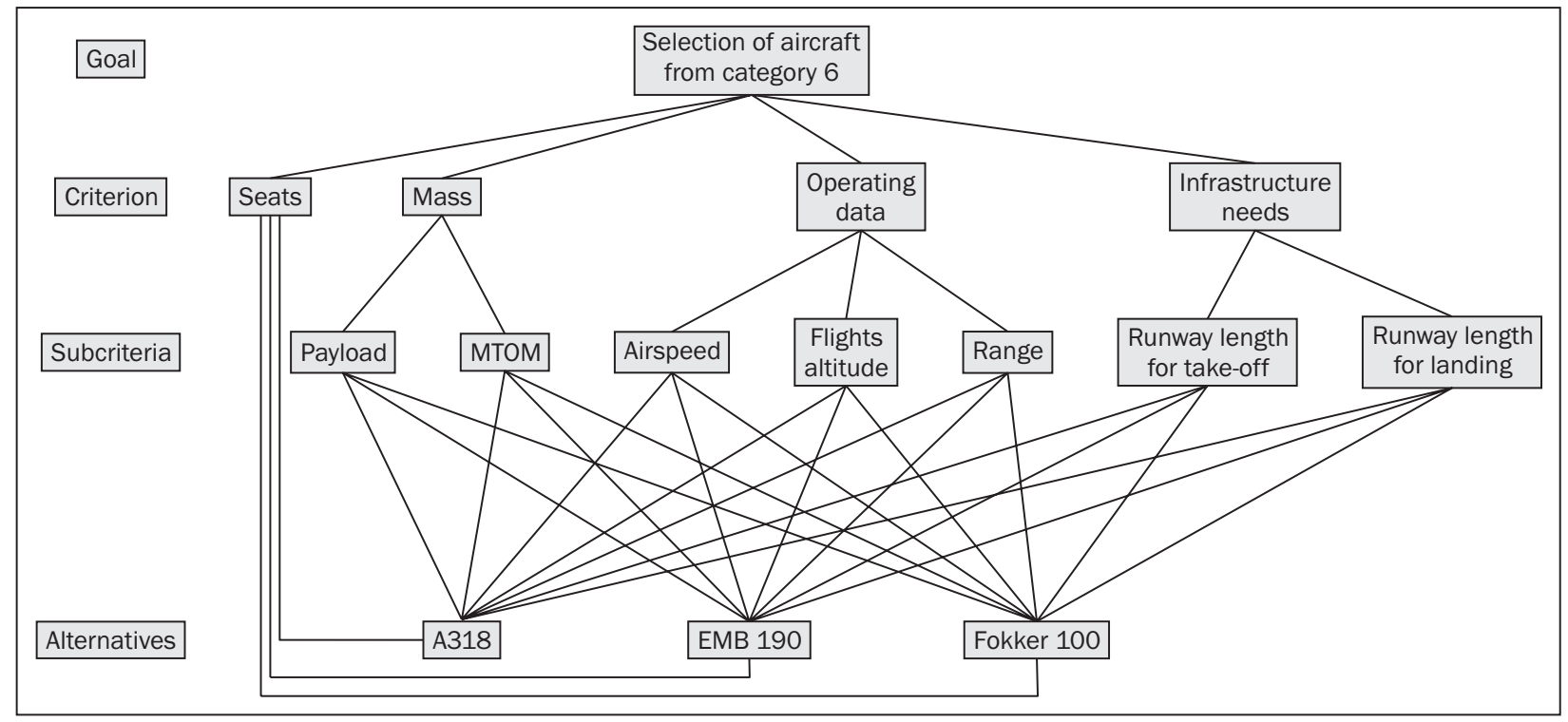

Figure 4 - Scheme of the hierarchical structure of multi-criteria analysis model in the function of selecting the optimal aircraft from Category 6 [7] 
Dash8-Q400 lacks adequate capacity to perform the flight to distant destinations. Turboprop aircraft are competitive with jet engine aircraft at distances of up to $740 \mathrm{~km}$, and therefore aircraft with jet engines should be applied for all routes over this distance. The exceptions in this case are routes for short distances at which higher demand is expected.

Multi-criteria analysis (Figure 4) proved that the optimal aircraft for medium-haul flight is Embraer 190. The analysis showed that the use of larger aircraft from companies Boeing and Airbus, the aircraft that are usually used in the low-cost segment, was of questionable economic viability, i.e. it would be questionable to insure filling of the passenger cabin. Embrear 190 is considered as the most efficient aircraft available in the range of 98-114 seats. The break-even point for the E190 aircraft is 61 percent ( 65 seats - the rest of the seats are potential profit) and in par with the Airbus A320, which is much larger in the seating capacity.

The reason for proposing a combined fleet is the need of uniform connecting of the Croatian territory and the immediate region with the aircraft for which the optimal choice is Dash8-Q400. If in this sector only EMB 190 aircraft were applied, it could not provide the necessary filling of 61 percent. Dash8-Q400 aircraft must ensure filling of 44 seats which is realistic to be insured concerning the traffic demand.

On each day of the week 19 flights would be realized from the Zagreb Airport to other destinations. To most of the destinations the flights would be on the daily basis, except in the case of Frankfurt - Hahn Airport to which flights would be made twice a day, the Madrid Barajas Airport (4 times a week) and BarceIona - Girona Airport ( 3 times a week) that would be flying on the principle of daily rotation of aircraft and the Prague Airport (4 times a week) and the Podgorica Airport (3 times a week) which would also fly on a rotating basis.

For the operation of the proposed schedule it is necessary to operate with three aircraft Embraer 190 and two aircraft Dash8-Q400. Two aircraft Embraer 190 connect Croatia on a daily basis with the most frequent European destinations without rotation, while the third Embraer 190 would rotate daily flights to Madrid (1_3_5_7) and Barcelona (_2_4_6_). With Dash8Q400 embarking from airports Split, Dubrovnik, Pula and Zadar additional load factor of Ebraer 190 would be ensured on international flights. The first Dash aircraft would take off from Split or Dubrovnik (Split 1_3_5_7, Dubrovnik _2_4_6_). The second Dash would take off from Pula or Zadar (Pula 1_3_5_7, Zadar_2_4_6_).

In case that any of these destinations proved unprofitable in a longer period, it is necessary to suspend the flights and find a new potential destination or to increase the frequency to one of the existing ones.

\section{CONCLUSION}

In the future low-cost airlines should work on attracting a larger number of small and midsize business travellers and expand the medium-haul routes, with the same low-cost formula, and thus adopt an offensive rather than a defensive strategy. The growth rates of low-cost airlines that were recorded in the last decade will slow down, except in Central and Eastern Europe, where there is still unused potential. Because of possible saturation in the European market over the next 10-15 years, which is already happening in the U.S. and the UK, in the near future the companies should plan to enter the fast-growing markets of the Middle East and Asia.

A significant advantage of low-cost airlines compared to traditional airlines will continue to be a denser seat disposition and the frequency of flights because traditional operators are not able to modify the existing models if they want to retain the primacy in the transport of business passengers, landing at primary airports and exploit the benefits of network connections between the primary airports.

To ensure optimal loading of aircraft that fly from Croatia to international destinations, the Zagreb Airport would be the hub which would collect passengers from the morning flights from other Croatian airports and then distribute them to final destinations. The proposed model represents a deviation from the base low-cost model that assumes a point-to-point network model. The reason for the proposition of a hub-andspoke network model is a specific local environment, i.e. Croatia to a wide network of seven international airports has a little more than 4.5 million inhabitants. With the implementation of the hub-and-spoke model Zagreb can be linked with the rest of the proposed Croatian airports and provide the filling on international flights that generate the most revenues. Direct connection (point-to-point) of other Croatian airports with the proposed destinations is feasible during the summer tourist season when there is a demand for additional flights to the coastal airports, while the principle of direct connectivity in the rest of the year would not be possible without generating additional costs due to poor market potential.

The testing of the proposed model is not operationally possible, especially because of the financial scale of such a project. It is possible, however, by the theoretical simulations in interdisciplinary research with economic analysts to test the effectiveness of the proposed model.

Despite facing many challenges, the low-cost business model is sustainable in Europe, as it has been for many years in the U.S. Traditional companies have plenty of room for lowering the unit costs, but not enough to significantly threaten or be closer to the costs of low-cost airlines on short-haul routes. In Eu- 
rope, North America and, eventually, in most major regions, the low-cost airlines will become the dominant carrier in domestic transport and the transport for short-haul routes. They are not a passing phase. They are here to stay and dominate in the most markets they serve.

\section{Dr. SC. ANDRIJA VIDOVIĆ}

E-mail: avidovic@fpz.hr

Dr. Sc. SANJA STEINER

E-mail: ssteiner@fpz.hr

Sveučilište u Zagrebu, Fakultet prometnih znanosti

Vukelićeva 4, 10000 Zagreb, Hrvatska

Mr. Sc. IGOR ŠTIMAC

E-mail: istimac@zagreb-airport.hr

Zračna luka Zagreb

Pleso bb, 10150 Zagreb, Hrvatska

\section{SAŽETAK}

\section{POTENCIJALI RAZVOJA NISKOTARIFNE ZRAKOPLOVNE OPERATIVE U REPUBLICI HRVATSKOJ}

Liberalizacija zrakoplovnog tržišta omogućila je niskotarifnim zrakoplovnim kompanijama preuzimanje znatnog udjela u zrakoplovnom tržištu. Prednosti niskotarifnog modela su višestruke i za putnike i za sekundarne i regionalne aerodrome, zapostavljene u prošlosti, koji njihovim dolaskom bilježe znatne priljeve putnika.

U strukturi zračnog prometa Republike Hrvatske, zadnjih se deset godina bilježi progresivan rast udjela niskotarifnih zrakoplovnih operacija (stranih) što sugerira potencijale operacionalizacije hrvatske niskotarifne zrakoplovne operative.

U radu su definirani kriteriji modeliranja primjenjive niskotarifne zrakoplovne operative u Republici Hrvatskoj u relevantnim sadržajima flotnog menadžmenta, rutnog umrežavanja i prometno-tehnoloških procesa operatera. Analizira se dinamika operative niskotarifnih zrakoplovnih kompanija u strukturi zračnog prometa Republike Hrvatske, te utjecaj na status prometa zračnih luka i nacionalnog operatera.

\section{KLUČNE RIJEČI}

niskotarifna zrakoplovna kompanija, tradicionalna zrakoplovna kompanija, zračna luka, rutna mreža, flotni menadžment

\section{LITERATURE}

[1] Piga, C. A., Fillipi, N., Bachis, E.: Booking and flying with low cost airlines, International Journal of Tourism Research, Vol. 4, pp. 237-249, 2001

[2] McKenzie, B.: Low Cost Carriers -Interiors, $9^{\text {th }}$ Annual Aircraft Interior Design \& Cost Management Conference, Nice, 2007

[3] Doganis, R.: The Airline Business, Second edition, Routledge, New York, 2007

[4] Dennis, N.: Can the European Low-cost Airline Boom Continue?: Implications for regional airports, $44^{\text {th }}$ European Congress of the European Regional Science Association, Porto, 2004

[5] Vince, D.: Razvoj zračnog prometa u funkciji razvoja ekonomskih odnosa Republike Hrvatske s inozemstvom, Scientific Master's Thesis, Faculty of Economics, Zagreb, Republic of Croatia, 2009

[6] Mišetić, I.: Marketing u funkciji regionalnog pozicioniranja zrakoplovnog prijevoznika, Lectures held at the Faculty of Traffic and Transport Sciences, Zagreb, 2009

[7] Vidović, A.: Model niskotarifne zrakoplovne operative $u$ Hrvatskoj, Doctoral Dissertation, Faculty of Traffic and Transport Sciences, Zagreb, Republic of Croatia, 2010 